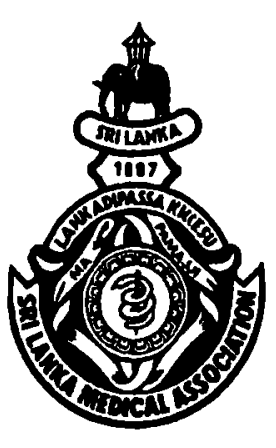

All communications should be addressed to The Editors, CMJ

\section{Edltor Emeritus}

Dr Chris G Uragoda MD, FRCP

Editors

Colvin Goonaratna FRCP, PhD Janaka de Silva DPhil, FRCP

\section{Assistant Editors}

Dennis Aloysius MBBS, FCGP

D N Atukorala MD, FACP

Ranjan Dias MS, FRCS

Saman Gunatilake MD, FRCP

Prasad Kumarasinghe MBBS, MD

Nalini Rodrigo MBBS, FRCA

Nimal Senanayake MD, FRCP

Harshalal R Seneviratne DM, FRCOG

Damani de Silva MD, MRCPsych

Harendra de Silva FRCP, MSc

Tissa Vitarana MD, PhD

International Advisory Board

Richard Smith FRCP

London, UK.

Raja Bandaranayake FRACS, PhD New South Wales, Australia.

Kasuko Ito MD

Gifu, Japan.

R K Tandon MD, PhD

Now Delhi, India.

Continued overteal

\section{THE CEYLON MEDICAL JOURNAL}

\author{
Established 1887 \\ The Official Publication of the \\ Sri Lanka Medical Association \\ Volume 45, No.4, December 2000 \\ Quarterly ISSN 0009-0875
}

Leading articles

\section{Towards achieving civilised status for state hospitals}

\section{Let's start by giving every patient a bed}

"Every day young doctors and the nursing staff working in public sector hospital wards are forced to take the most degrading decision of allocating patients to the floor. Human dignity, care and compassion, as very clearly stated in the Universal Declaration of Human Rights, the guiding principles of the Commonwealth Medical Association and in the SLMA Declaration on Health, are surely the right of every patient? It is the duty primarily of those attending on patients, and indeed of society as a whole, to see that this right is respected. Why have we failed to do so ?" asks Dr Eugene Corea, a family physician. He deserves great praise for bringing this hitherto unaddressed issue of "floored patients" in state hospitals into public focus even though it does not directly affect him $(1,2)$. His impassioned plea of "No more floor shows please", implying that every patient admitted to a ward should be given a bed, is a step in the right direction, if our society is to be deemed civilised. The Sri Lanka Medical Association (SLMA) should take the lead in rectifying this human rights violation.

As medical specialists we are caught between the devil of keeping patients on the floor and the deep blue sea of not accepting any once the beds are full. Unplanned patient transfers from other hospitals and frequent internal referrals put tremendous pressure on specialists. Personally, I do not admit patients to the ward directly from the private sector, but yet face the problem of having several floor patients. Battle casualties and civilian victims of terrorist bomb blasts inundate the surgical wards of some hospitals every now and then.

With the exception of nurses, doctors, clergyman and politicians (the categories receiving preferential treatment), nearly all other categories have suffered at some time the degrading and humiliating treatment of being consigned to the floor in state hospital wards by health care workers. The cardinal question a doctor should ask himself / herself is "Am I going to allow my mother, father, brother, sister, spouse or child to be put on the floor?" Invariably, the answer would be in the negative. Then why are we still blind to this injustice to mankind? Furthermore, health care workers have received brickbats from patients occupying beds when they are suddenly relegated to the floor, when actually such blame should be directed at the health planners in the Health Ministry, especially the Health Minister.

The SLMA as an authoritative body must convince the Health Ministry officials that every patient admitted to hospital is entitled to a bed, and set up a working party to ensure that this goal is achieved.

References

1. Corea E. Some patients "floored" in hospital wards. Sunday Observer, 9 April, 2000 p.5.

2. Corea E. There are people on the floor. Sri Lankan Family Physician 1998; 21: $31-2$.

Serozsha A S Goonewardena, Urological Surgeon, National Hospital of Sri Lanka, Colombo. 